Het Dementie Formularium 


\section{Het Dementie Formularium}

\section{Een praktische leidraad}

Dr. E.A.C.M. Sanders en

Drs. W. Garenfeld

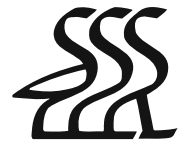

Bohn Stafleu van Loghum Houten 2009 
(C) 2009 Bohn Stafleu van Loghum, onderdeel van Springer Uitgeverij

Alle rechten voorbehouden. Niets uit deze uitgave mag worden verveelvoudigd, opgeslagen in een geautomatiseerd gegevensbestand, of openbaar gemaakt, in enige vorm of op enige wijze, hetzij elektronisch, mechanisch, door fotokopieën of opnamen, hetzij op enige andere manier, zonder voorafgaande schriftelijke toestemming van de uitgever.

Voor zover het maken van kopieën uit deze uitgave is toegestaan op grond van artikel I6b Auteurswet I9I2 $\mathrm{j}^{\circ}$ het Besluit van 20 juni I974, Stb. 35I, zoals gewijzigd bij Besluit van 23 augustus I985, Stb. 47I en artikel I7 Auteurswet I9I2, dient men de daarvoor wettelijk verschuldigde vergoedingen te voldoen aan de Stichting Reprorecht (Postbus 305I, 2130 KB Hoofddorp). Voor het overnemen van (een) gedeelte(n) uit deze uitgave in bloemlezingen, readers en andere compilatiewerken (artikel I6 Auteurswet I9I2) dient men zich tot de uitgever te wenden.

Samensteller(s) en uitgever zijn zich volledig bewust van hun taak een betrouwbare uitgave te verzorgen. Niettemin kunnen zij geen aansprakelijkheid aanvaarden voor drukfouten en andere onjuistheden die eventueel in deze uitgave voorkomen.

ISBN $978903{ }_{3} 6$ II 82

NUR $871 / 870$

Ontwerp omslag: Designworks, Oud Gastel

Ontwerp binnenwerk: Studio Bassa, Culemborg

Automatische opmaak: Cross Media Solutions - Ten Brink, Alphen aan den Rijn

Bohn Stafleu van Loghum

Het Spoor 2

Postbus 246

3990 GA Houten

www.bsl.nl 


\section{Inhoud}

$\begin{array}{ll}\text { Auteurs } & 9\end{array}$

$\begin{array}{ll}\text { Voorwoord } & \text { IO }\end{array}$

I Inleiding II

2 Classificatie van patiënten met dementiële syndromen $\quad$ I3

2.I De ziekte van Alzheimer I3

2.2 Incidentie van dementie en van de ziekte van Alzheimer I8

2.3 Genetische factoren I8

2.4 Lewy-bodydementie 20

2.5 Frontotemporale dementie oftewel de ziekte van Pick 22

2.6 Normal-pressure hydrocephalus (NPH) 24

$\begin{array}{lll}2.7 & \text { Thalamische dementie } & 24\end{array}$

2.8 De ziekte van Creutzfeldt-Jakob 24

$2.9 \quad$ Vasculaire dementie 25

2.Io Leuko-araiose 26

2.II Cognitievermindering en veel voorkomende neurologische aandoeningen $\quad 27$

2.I2 Enkele reversibele oorzaken van dementie 29

3 Diagnostiek 3I

3.I Anamnese en heteroanamnese 3I

3.2 Dementie en delier 33

$3 \cdot 3$ Laboratoriumtests 34

$3 \cdot 3$ Liquordiagnostiek $\quad 36$

3.4 Elektro-encefalografie (eeg) 37

$\begin{array}{ll}3 \cdot 5 & \text { Neuropsychologisch onderzoek }\end{array}$

$\begin{array}{lll}3.6 & 37\end{array}$ 
$4 \quad$ Enkele instrumenten voor screening van de cognitieve functies en de GDetS/Fast-stagering van dementie

4.I De Mini Mental State Examination (MMSE) 39

$4.2 \quad$ Kloktekentest 40

4.3 Verkorte informant-vragenlijst over cognitieve achteruitgang bij ouderen (Informant Questionnaire on Cognitive Decline in the Elderly - Nederlandse versie (IQCODE-N))

4.4 Observatielijst voor vroege symptomen van dementie (OLD)

4.5 De Alzheimer Disease Assessment Scale (ADAS-Cog) 4I

4.6 Cambridge cognitieve screeningstest - herziene Nederlandse versie (Camcog-R/N)

4.7 Globale Deterioratie Schaal (GDetS) en de Functional Assessment Staging (FAST)

$5 \quad$ Farmacotherapie bij dementie

5.I Acetylcholinesteraseremmers

5.2 Nieuwe (anti)cholinerge medicatie

5.3 Glutamaat, aspartaat en NMDA-antagonisten

$5 \cdot 4$ Ontstekingsremmers

$5 \cdot 5$ Oestrogeensuppletie

5.6 Statines

52

5.7 Antioxidanten, onder meer vitamine E, en

5.8 Nieuwe ontwikkelingen

5.9 Psychiatrische symptomen en gedragsstoornissen bij dementie

6 De zorgketen bij dementie $\quad 58$

6.I Demografische ontwikkelingen 58

6.2 Mantelzorg, thuiszorg en huisarts 59

6.3 Geheugenpolikliniek 60

6.4 Zorgdiagnostiek 6I

6.5 Dementieconsulenten 6I

6.6 Groepsondersteuning 62

6.7 Zorgmakelaars 62

6.8 Psychogeriatrische dagbehandeling en

6.9 Enkele interventies in de zorgketen 63 
Lijst van afkortingen 65

Geneesmiddelenoverzicht 68

Literatuur 70 70 


\section{Auteurs}

Dr. E.A.C.M. Sanders, neuroloog, Amphia Ziekenhuis, Breda

Drs. W. Garenfeld, psychiater, GGZ Breburggroep, Tilburg 


\section{Voorwoord}

Dementie wordt gekenmerkt door het geleidelijk achteruitgaan van de cognitieve functies. Geheugenstoornissen staan hierbij op de voorgrond. Er zijn verschillende oorzaken van dementie; de ziekte van Alzheimer en cognitieverlies als gevolg van vasculaire stoornissen zijn de meest voorkomende. Op dit moment zijn er in Nederland naar schatting 150.000 tot 200.000 patiënten die lijden aan enige vorm van dementie. In $2050 \mathrm{zal}$ dit aantal zijn toegenomen tot ongeveer 400.000. Vanuit volksgezondheidsgezichtspunt is dementie een veelomvattend probleem. Na het vaststellen van de diagnose, bijvoorbeeld de ziekte van Alzheimer, leeft de patiënt nog ongeveer acht tot tien jaar. Sinds I 998 blijken bepaalde vormen van dementie beïnvloed te kunnen worden door het gebruik van acetylcholinesteraseremmende middelen. Geleidelijk is duidelijk geworden dat vroege behandeling hiermee langdurig profijt kan geven. Dit formularium is bedoeld als praktische leidraad voor het vaststellen van de diagnose dementie met de daarbij behorende oorzaak. Daarnaast is het bedoeld om een handreiking te geven voor het gebruik van de diverse therapeutische middelen ook als gedragsstoornissen meer op de voorgrond staan.

Breda/Tilburg, november 2009,

E.A.C.M. Sanders, neuroloog, Breda

W. Garenfeld, psychiater ouderenzorg, Tilburg 